\title{
Patenting rationales of academic entrepreneurs in weak and strong organizational regimes
}

\author{
SASCHA G. WALTER \\ Reader for Entrepreneurship and Innovation \\ Lancaster University \\ Lancaster, LA1 4YX, UK \\ Tel: +44 1524594847 \\ Fax: +44 15245 \\ Email: s.walter@lancaster.ac.uk
}

\author{
ARNE SCHMIDT \\ Technology and Innovation Management \\ Senvion SE \\ Osterrönfeld, 24783, Germany \\ Tel: +49 433113139148 \\ Fax: +49 433113139999 \\ Email: arne.schmidt@senvion.com
}

\author{
ACHIM WALTER \\ Professor for Entrepreneurship and Innovation Management \\ Institute for Innovation Research, Christian-Albrechts-University Kiel \\ Kiel, 24118, Germany \\ Tel: +49431 8803999 \\ Fax: +494318803213 \\ Email: walter@bwl.uni-kiel.de
}

A later version is forthcoming at Research Policy.

\begin{abstract}
This study explores why academic entrepreneurs seek patents for spin-off technology in weak organizational regimes (the employee owns her inventions) and strong organizational regimes (the employer, i.e. the university or research organization, owns these inventions). Specifically, we examine organizational and founding team characteristics as alternative explanations. Matched data of academic spin-offs from both contexts combined with patent data shows that founding team characteristics (expert knowledge and entrepreneurial orientation) matter in weak, but not strong regimes. In contrast, organizational patenting norms are the key driver of patenting in strong, but not weak regimes. We discuss the implications of our results for the current literature and technology transfer policies.
\end{abstract}

Acknowledgements: We thank Petra Dickel, Manoj Gupte, and Felix Riesenhuber for their invaluable help in collecting data. Prior versions of the manuscript have been presented on the BCERC 2015 and the AOM 2015. An abbreviated, earlier version has been published as Walter, S.G., Schmidt, A., Walter, A. 2015. Patenting behavior by academic entrepreneurs: The role of the organizational regime. In: Humphreys, J. (Ed.). Proceedings of the Seventyfifth Annual Meeting of the Academy of Management, pp. 1-6.

Keywords: academic entrepreneurs, patent propensity, technology spin-offs JEL-Classification: L26, O31, O34 


\section{INTRODUCTION}

Legal reforms in many countries, such as the Bayh-Dole act in the US (Shane, 2004a) or the Employees' Inventions Act in Germany (Harhoff and Hoisl, 2007), have given property rights in federally funded research to the employer. Often this initiated a shift from a 'weak organizational regime' (i.e., the employee holds the property rights in her inventions made at work) to a 'strong organizational regime' (i.e., the employer - the university or research organization-holds property rights in employee inventions). This change seems to have radically altered the way academic entrepreneurs (i.e., scientists who commercially exploit their discoveries by creating their own ventures) can protect their firms’ knowledge base. But how drastic is the change really? Some scholars now view the employer as the sole decisionmaker in patenting (Shane, 2004). Other scholars highlight the great informal influence scientists can still exert on their employers' decision to patent their inventions or not (Agrawal, 2006; Jensen and Thursby, 2001). However, to date, the literature has been resoundingly silent on the question why academic entrepreneurs seek patents and what difference the organizational regime makes in this context. This oversight is surprising given the ongoing debate about the efficacy of patents (e.g., Arundel, 2001; Lanjouw and Schankerman, 2004; Lowe, 1993; Shane, 2001)—in particular for start-ups and small firms (Leiponen and Byma, 2009; Thomä and Bizer, 2013)—and the threat that patenting could become an organizational automatism also in situations where other protection strategies are advisable.

In exploring patenting rationales, our study builds on different streams of existing research. One stream has suggested that scientists who conduct more applied research (Sellenthin, 2009), have published intensively (Azoulay et al., 2007; Dietz and Bozeman, 2005; Van Looy et al., 2006), gained more industry experience (D’Este and Perkmann, 2011; Meyer, 2006), or received industry funding (Carayol, 2007; Landry et al., 2007), are more likely to disclose and let the organization patent their inventions. A second stream has 
suggested that firms, which are intensively conducting R\&D (Brouwer and Kleinknecht, 1999), export-oriented (Arundel and Kabla, 1998), and active in certain industries (Mansfield, 1986), are more likely to patent. A third stream has examined impacts of Bayh-Dole-like acts, suggesting, for instance, that the Bayh-Dole act had little effect on university patenting in general, but was influential only in certain fields and for certain universities (Henderson et al., 1998; Mowery and Ziedonis, 2002; Sampat et al., 2003; Shane, 2004a). Universities outside the US, while showing increasing interest in claiming their intellectual property rights (Della Malva et al., 2013; Dornbusch and Neuhäusler, 2015), were found to initially lack the necessary support infrastructure to fully benefit from such legal reforms (Baldini, 2009). Research within this stream also suggests that US universities own a higher share of academic patents than their European counterparts, arguably as a result of the time lag in legal reforms (Lissoni et al., 2008; Lissoni, 2012). Another study shows that the size of technology transfer offices, of which many were created after the reforms (Sampat, 2006), promotes start-up activity, but not patenting activity (Van Looy et al., 2011).

Despite substantial scholarship, a few significant gaps remain in our understanding of academic entrepreneurs’ patenting. First, previous findings for scientists and firms are not necessarily generalizable to academic entrepreneurs: Unlike firms, academic entrepreneurs have, at least formally, lost discretion over patenting in countries implementing Bayh-Dolelike acts. Academic entrepreneurs can retain greater preference for publishing instead of patenting intellectual capital than entrepreneurs with business backgrounds (Link and Ruhm, 2011). Unlike non-founding scientists, academic entrepreneurs take financial responsibility for commercializing their inventions, can suffer from losing control over the invention by patenting via the employer (Shane, 2002; Thursby and Thursby, 2002), and have to balance academic and entrepreneurial careers as well as university and spin-off interests in patenting (Nicolaou and Birley, 2003). Second, although impacts of Bayh-Dole-like acts have been widely investigated, no study (that we know of) has illuminated how patenting by academic 
entrepreneurs differs in weak and strong organizational regimes. While the propensity to engage in patenting processes may hinge on a mix of individual and organizational influences (Azoulay et al., 2007; Bercovitz and Feldman, 2008) it is still unclear whether and how BayhDole-like acts affect the relative importance of these influences.

To address the above gaps, this study examines the relative influence of founding team characteristics (expert knowledge and entrepreneurial orientation) vis-à-vis organizational characteristics (publication norms, patenting norms, and patenting capabilities) on academic entrepreneurs' propensity to seek patents. More specifically, we compare the role of these characteristics in two contexts, namely weak and strong organizational regimes. We use Ajzen's (1991) theory of planned behavior to illuminate the theoretical 'black box' surrounding our hypothesized relationships. A matched sample of spin-offs from public universities and public research organizations in Germany allowed us to study different organizational regimes. The university sample represents weak organizational regimes by containing spin-offs founded prior the reform of the Employees' Inventions Act in 2002-a time when university professors, lecturers, and scientific assistants still had de jure ownership in their inventions (Harhoff and Hoisl, 2007). Public research organizations represent strong organizational regimes as they are governed under the Employees’ Inventions Act of 1957, granting the employer full ownership in employee inventions.

This article contributes to the extant literature in several ways. First, our results indicate that in strong organizational regimes, only organizational patenting norms, but not expert knowledge or entrepreneurial orientation matter for patenting. This extends the literature on Bayh-Dole-like acts by showing how much the implementation of such acts can affect patenting rationales of academic entrepreneurs up to a point, where patenting might become an organizational automatism. Second, our focus on academic entrepreneurs adds to the wider literature on patenting that has been limited to either scientists (e.g., Baldini, 2009) or established firms (e.g., Arundel and Kabla, 1998). Our findings suggest that academic 
entrepreneurs patent for reasons partly similar, partly different to those identified for scientists and firms. Third, scholars have theorized that the organizational influence on patenting may flow via two mechanisms, including organizational norms and organizational support (Baldini, 2009; Bercovitz and Feldman, 2008; Sellenthin, 2009). This study is one of the first to test both possibilities in concert. Significant findings for organizational patenting norms, but not organizational patenting capabilities seem to confirm the first explanation. Finally, our study contributes to the long-standing debate on the relationship between patenting and publishing (e.g., Geuna and Nesta, 2006; Larsen, 2011). According to our findings for academic entrepreneurs, there is no significant link between the two domains, suggesting that they co-exist rather than complement or substitute one another.

\section{THEORETICAL DEVELOPMENT}

In deciding whether to patent or not, academic entrepreneurs have to weigh several benefits and risks of patenting. Patents can safeguard their spin-off's knowledge-base against early imitation by defining property rights (Harter, 1994), attract venture capital (Wright et al., 2006; Mann and Sager, 2007), support inter-firm partnering (Hertzfeld et al., 2006), and, if effective, yield substantial competitive advantage (Kaiser, 2009; Song et al., 2008). Their signaling function can make patents a necessary cost for ensuring a start-up’s viability (Levitas and McFadyen, 2009). On the other hand, patents require the disclosure of critical information, thereby enabling competitors to imitate or 'invent around' a patent (Arundel, 2001; Kultti et al., 2007). Patenting is considerably time-consuming and expensive and can be a suboptimal strategy for spin-offs lacking the resources to effectively litigate and enforce their rights in cases of infringement (Arundel, 2001; Lanjouw and Schankerman, 2004).

The patenting decision does not always rest with the academic entrepreneur alone because jurisdictions handle property rights to employee inventions differently. Some jurisdictions permit the inventor to retain full property rights and to independently file a 
patent (Sellenthin, 2009). Yet, even in this 'weak organizational regime', some academic entrepreneurs may involve the organization in the patenting process, in order to benefit from organizational support in writing and, if necessary, defending a patent or to comply with general expectations (Bramwell and Wolfe, 2008; Sampat, 2006). Other jurisdictions entitle organizations to patent on behalf of their employees, if the invention results from federally funded research. These ‘strong organizational regimes’ result from legal regulations that have been in place for research organizations for a long time (Harhoff and Hoisl, 2007). In contrast, many universities shifted to a strong regime through legal reforms that started in the 1980s with the Bayh-Dole Act in the US (Mowery et al., 2001) and were later also implemented in other countries (e.g., Baldini, 2009). The inventor is required to disclose discoveries made during working time, let the organization decide whether to patent and, in case, obtain a license prior to firm founding. Otherwise, the inventor is free to patent in his or her own name. To some academic entrepreneurs, this may appear as a choice between letting the technology transfer office (TTO) file a patent, thereby risking to lose control over the invention (Shane, 2002; Thursby and Thursby, 2002), or creating a venture without filing a patent prior to founding and accepting the involved legal and ethical risks (Aldridge and Audretsch, 2010; Bercovitz and Feldman, 2008). ${ }^{1}$ Other academic entrepreneurs may welcome the organizational support. However, even in a strong organizational regime, inventors can informally influence the organization's decision to patent and license back because they can make the invention appear more or less valuable in the disclosure, the commercialization success critically depends on the inventor's cooperation (Agrawal, 2006; Jensen and Thursby, 2001), and many organizations do not patent before a licensee is found (Bercovitz and Feldman, 2008; Shane, 2002). ${ }^{2}$

\footnotetext{
${ }^{1}$ Many academic inventors do not disclose their inventions (Bercovitz and Feldman, 2008; Landry et al., 2007; Jensen et al., 2003). Of these, some are interested in commercialization but consider the TTO difficult to work with or are unwilling to share revenues with the university (Thursby et al., 2009).

${ }^{2}$ Our interviews with inventors showed that some universities even stop to renew patents, once the inventor has changed the employer.
} 
To further explore the black box between patenting rationales and patenting, we adopt the lens of the theory of planned behavior (Ajzen, 1991). In its basic tenet, behavior is driven by intentions and intentions, in turn, are determined by attitudes, i.e. the appraisal of the behavior, subjective norms, i.e. social pressures to perform or not a given behavior, and perceived behavioral control, i.e. the perceived ease or difficulty of performing a behavior. We use the theory only to understand the mechanisms behind our hypothesized relationships and do not test it empirically. However, meta-analyses have confirmed the theory's strong explanatory power for various behaviors (e.g., Armitage and Conner, 2001). In keeping with prior research, our study models engagement in patenting processes as a function of individual and organizational influences (Azoulay et al., 2007; Bercovitz and Feldman, 2008). ${ }^{3}$ Thus, in the following sections, we will theorize that the effect of founding team and organizational characteristics on the tendency to seek patents flows via the attitudes, subjective norms, and/or perceived behavioral control. Founding team characteristics include expert knowledge and entrepreneurial orientation, a choice consistent with prior findings for the importance of knowledge and motivation in an entrepreneurship context (e.g., McMullen and Shepherd, 2006). In line with the extant literature (e.g., Bercovitz and Feldman, 2008), organizational characteristics include patenting norms and publication norms. We add organizational patenting capabilities, a theoretically important aspect (Mowery et al., 2002) that has received increasing attention (APE-INV Project, 2009; Meyer, 2006; Van Looy et al., 2006; Van Looy et al., 2011), but is still worth to be studied in the more specific context of academic entrepreneurship.

\footnotetext{
${ }^{3}$ Some entrepreneurship scholars have argued that spin-offs are dependent on patentability considerations and tend to be created in fields with high patent effectiveness (e.g., Lowe, 1993; Shane, 2001). Many founders should therefore jointly take the decision to start a venture and patent. In contrast, our model views patent decisions as determined by various influences. Thus, we conceptually disentangle the decision to patent from the decision to create a venture.
} 


\section{Founding team characteristics}

\section{Expert Knowledge}

Expert knowledge refers to the extent to which founders are experts in their technological fields and knowledge about their venture's core technology is unavailable via external sources. Greater expert knowledge should drive academic entrepreneurs to patent more actively due to a more favorable attitude towards patenting. In established firms, different individuals possess critical technological know-how, manage and own the firm, causing agency problems. Such firms often patent to safeguard against knowledge losses when key R\&D employees quit to join or start a rival (Kim and Marschke, 2005). In contrast, academic entrepreneurs jointly have critical expert knowledge about the core technology and ownership of their spin-offs. Such knowledge is often not wide-spread and should play a special role for patenting by these entrepreneurs (Agrawal, 2006). If knowledge is scarce, the human capital retained by the discovering scientists becomes the main resource around which firms are built (Zucker et al., 1998). To the extent to which expert knowledge is also tacit, it can serve as a source of competitive advantage (Hatch and Dyer, 2004). Patenting requires to partly codify such knowledge and entails, at least in part, a shift from a secrecy defense enabled through tacit expert knowledge to a patenting defense.

Given their expertise, scientists with expert knowledge are more likely to arrive at novel and non-obvious discoveries, possibly applicable to patent protection (Calderini et al., 2007). Often such knowledge cannot be completely codified or scientists have few incentives to do so because returns to codification are below returns to time invested in further research (Zucker et al., 2002). Nevertheless, by filing at least some patents, entrepreneurs can reap key benefits from patenting, such as building reputation (Blind et al., 2006) or attracting venture capital (Wright et al., 2006). Even if these patents fail, sufficient expert knowledge remains to shield the venture’s knowledge base against imitation. For instance, Agrawal (2006) illustrated the pivotal role of inventor knowledge by demonstrating that licensees who directly 
engaged the inventor realized greater commercialization success. Moreover, Arundel (2001) argues that patents and secrecy are not always mutually exclusive appropriation mechanisms, but can be used sequentially or simultaneously. Thus, expert knowledge can complement patents, thereby providing a more effective shield against imitation. Extensive knowledge stocks allow to employ a 'hybrid protection strategy' by patenting one (part of an) invention and keeping another one secret. If competitors require both parts to imitate a spin-off's core technology, it is safe as long as one safeguard holds. Thus, expert knowledge allows academic entrepreneurs to benefit from patenting with fewer risks involved, thereby shaping more positive attitudes towards patenting. Thus, ceteris paribus,

Hypothesis 1a. The more extensive the expert knowledge, the higher the patent propensity of academic entrepreneurs.

\section{Entrepreneurial Orientation}

Entrepreneurial-oriented academics have, as we suggest below, more positive attitudes towards patenting and will therefore more actively seek patents. Entrepreneurial orientation is defined as the processes, structures, and behaviors that are characterized by innovativeness, proactiveness, and risk taking (Covin and Slevin, 1989; Miller and Friesen, 1983). Innovativeness reflects the tendency to actively support new ideas, novelty, experimentation, and creative solutions in pursuit of competitive advantage. Risk-taking involves a tendency to take business-related chances regarding strategic actions in uncertain environments. Proactiveness denotes a tendency to anticipate and act on future needs by introducing new products and services ahead of competition (Covin and Slevin, 1989; Lumpkin and Dess, 1996). Although originally conceptualized for firms, we suggest that entrepreneurial orientation also reflects the degree to which academic entrepreneurs have adopted entrepreneurial roles besides academic roles. The founders' mindset may, in turn, shape the 
entrepreneurial orientation of the emerging firm. This is consistent with research suggesting that values and norms of the founder or founding team become imprinted on the culture, routines, and collective identity of the emerging organization (Schein, 1983), which is believed to be relatively stable until founders start to depart (Bryant, 2014).

Academics engaging in commercialization activities tend to differ in the extent of accepting values of the business world, in particular the focus on private property and profits, vis-à-vis traditional academic values, in particular the focus on open knowledge sharing and peer recognition (Hoang and Gimeno, 2010; Jain et al., 2009). Entrepreneurial-oriented founders are likely to appreciate the opportunities that patent protection creates for developing their ventures. These founders compete on the basis of their technological skills in the belief that successful innovation emanates from effective R\&D (Atuahene-Gima and Ko, 2001). Since they strive for a technology leadership rather than a follower strategy (Lumpkin and Dess, 1996), patent protection creates favorable conditions for their experimentation with new technologies in search of creative product applications (Shane, 2001). A well-protected technological base allows pursuing a more aggressive growth strategy for technology ventures with a lower risk of knowledge misappropriation. Patents help ‘claim stakes’ on the market for technology and defend a leading position in a possible technology race that many spin-offs face at the outset. Overall, since patenting allows to engage in activities consistent with more entrepreneurial attitudes (Covin and Slevin, 1989), founders high in entrepreneurial orientation are more prone to seek patents. In contrast, founders with a stronger academic orientation are likely to perceive conflicts with traditional academic attitudes, leading them engage in only symbolic patenting or no patenting at all (Bercovitz and Feldman, 2008). Thus, ceteris paribus,

Hypothesis 1b. The higher the entrepreneurial orientation, the higher the patent propensity of academic entrepreneurs. 


\section{Organizational Characteristics}

\section{Organizational Patenting Norms}

Organizational patenting norms refer to social norms related to patenting. They should increase the patent propensity of academic entrepreneurs by shaping subjective norms. Elster (1989) defines social norms as unwritten codes of conduct within a group that stipulate acceptable behavior, are shared by others and partly sustained by their approval and disapproval. ${ }^{4}$ Individuals typically try to comply with norms to remain in good standing with a group and to, ultimately, maintain their membership (Kandori, 1992). Violations of norms often entail social sanctions, including internal sanctions such as guilt and remorse or external sanctions such as gossip and ostracism (Meek et al., 2010). In contrast to legal regulations, which are enforced by third-parties and out of self-interest, social norms are enforced by members of the group and not necessarily out of self-interest (Elster, 1989). This difference implies that legal reforms do not always induce changes in social norms. For instance, even after changes in jurisdiction, universities were found to vary in the degree to which they value commercialization activities besides traditional research activities (Bercovitz and Feldman, 2008; Di Gregorio and Shane, 2003) and enforce their legal rights to commercialize employee inventions (Mowery and Ziedonis, 2002; Sellenthin, 2009).

Organizational patenting norms reflect a strong culture of patenting that encourages further patenting activity. ${ }^{5}$ Such culture attracts faculty interested in patenting and socializes new organizational members into that norm (Owen-Smith and Powell, 2001). Moreover, academic entrepreneurs often retain their post in academia while pursuing entrepreneurial opportunities (Doutriaux, 1987). A long-term commitment to academia motivates them to

\footnotetext{
${ }^{4}$ Social norms must also be distinguished from moral norms that denote the perceived moral correctness or incorrectness of certain behaviors (Elster, 1989; Rivis et al., 2009).

${ }^{5}$ It should be noted that an entrepreneurial culture does not necessarily involve a patenting culture. In the words of an MIT scientists interviewed by Agrawal and Henderson (2002:50): “There's not a very strict patenting culture here, but we do support and encourage world-changing companies”.
} 
comply with norms salient in their university or research organization. Thus, strong patenting norms may result in, at least, symbolic patenting by academic entrepreneurs, even when in dissonance to norms gained by prior experience (Bercovitz and Feldman, 2008). Several studies highlight the great role of norms. For instance, Louis et al. (1989) found that researchers located in universities where many other faculty members engaged in patenting were also more likely to patent. According to research by Calderini et al. (2007), scientists from institutions having filed at least one patent tend to patent more actively. Findings by Bercovitz and Feldman (2008) suggested that when colleagues are active in invention disclosure, other researchers in that unit follow the example. Taken together, organizationlevel patenting norms influence individual-level subjective norms, which leads academic entrepreneurs to engage more actively in patenting. Thus, ceteris paribus,

Hypothesis 2a. The stronger the organizational patenting norms, the higher the patent propensity of academic entrepreneurs.

\section{Organizational Patenting Capabilities}

Organizational patenting capabilities refer to the capability of an organization to successfully file patents. Academic entrepreneurs from organizations that have mastered patenting processes in the past should be more willing to seek patents. Entrepreneurs pursuing a patenting strategy are interested in filing high-quality patents that secure competitive advantage and prevent competitors from inventing around the patent (Arundel, 2001). Although some organizations, particularly top universities in the US (Shane, 2002), have developed superior patenting routines, this is not always the case for other organizations and countries. Findings for Italy, for instance, indicate that a lack of support by the university administration hinders patenting (Baldini, 2009). Similarly, Owen-Smith and Powell (2001) suggest that faculty participation in patenting is driven by perceptions and capabilities of the 
university TTO. In Sellenthin's (2009) study, scientists in those organizations offering greater support patented more actively.

For academic entrepreneurs, involving the university or research organization can pose a considerable risk that the organization files low-quality patents. When an organizational patenting infrastructure is lacking or considered ineffective, academic entrepreneurs might decide to conceal a discovery from the administration, despite potential legal and ethical risks (Bercovitz and Feldman, 2008), or might exert influence to prevent patenting by the organization (Agrawal, 2006; Jensen and Thursby, 2001). However, studies suggest that universities can develop knowledge about patenting in a learning-by-doing process (Mowery et al., 2002; Owen-Smith and Powell, 2003). Sound organizational patenting routines can lower transaction costs involved in patenting and enhance the chances that a filed patent is eventually granted. According to Ajzen (1991), behavior is perceived as easier or more difficult, depending on past experience and anticipated impediments. Evidence of prior organizational success may increase the founders' confidence in patenting via the organization, thereby promoting perceived behavioral control and ultimately the willingness to patent. Thus, ceteris paribus,

Hypothesis 2b. The higher the organizational patenting capabilities, the higher the patent propensity of academic entrepreneurs.

\section{Organizational Publication Norms}

Organizational publication norms denote social norms related to publishing and should increase patent propensity. Given that the same research is often patentable and publishable (Agrawal and Henderson, 2002), scholars have intensively debated whether patenting and publishing are substitute or complementary activities (e.g., Azoulay et al., 2009; Crespi et al., 2011; Czarnitzki et al., 2009; Geuna and Nesta, 2006; Larsen, 2011; Meyer, 2006). 
Arguments for a substitution effect include that involvement in patenting, for instance, reduces the time available for publishing, encourages a shift away from more basic and publishable research to more commercially oriented research, and leads researchers to prefer secrecy to openly sharing and publishing their findings (Fabrizio and Di Minin, 2008). Moreover, published inventions are regarded as public knowledge and, thus, are not patentable anymore. Arguments for a complementary effect hold, for example, that patented research can still be submitted to a journal with a delay, patenting raises the awareness for new fruitful research areas, publishing increases the value of a patent by promoting the patented technology within the scientific community, and patenting provides additional funding for future projects (Fabrizio and Di Minin, 2008).

We argue that academic entrepreneurs from organizations emphasizing publication excellence are more likely to seek patents. These organizations typically attract, recruit, and train high-quality researchers and provide a context in which reputation building through publications is valued. To reinforce existing norms, organizational rewards, such as financial incentives or promotions, are often linked to publications, incentivizing organizational members to publish more extensively. Since academic entrepreneurs face the same publication pressures as their non-founding peers, a continuous flow of high-quality publications is typically required to develop their academic careers. However, scholarly publications also serve as an important information source for the industry (Cohen et al., 2002). Publications that are based on the same line of research as a spin-off can enable direct or potential competitors to access critical spin-off knowledge, posing considerable risks for its competitive position. Patenting first and publishing next is one possible way out of this dilemma and allows academic entrepreneurs to align academic and entrepreneurial career interests. Supporting this view, Carayol and Matt (2004) have shown that highly publishing labs also patent. Also Van Looy et al. (2006) found a complementary relationship between publication and patenting. If both activities are complementary, organizational publication 
norms may, like patenting norms, shape subjective norms conducive to publishing and patenting by academic entrepreneurs. Thus, ceteris paribus,

Hypothesis 2c. The stronger the organizational publication norms, the higher the patent propensity of academic entrepreneurs.

\section{Weak and Strong Organizational Regimes}

To recall, organizational regimes are defined by ownership of property rights to employee inventions: they are owned by the employee in weak regimes and by the employer in strong regimes. Thus, organizational regimes are shaped by the jurisdiction and depend on legal norms created and enforced by third parties (Elster, 1989). In strong regimes, employees are obliged to report an invention resulting from obligatory activity in the organization or based on experience or activities of the organization. The organization is then entitled to patent the invention or let the inventor file a patent in his or her own name (Harhoff and Hoisl, 2007). For the academic entrepreneur, this involves a risk not to obtain a license or only a non-exclusive license (Shane, 2002; Thursby and Thursby, 2002). Strong regimes can be plagued by ineffective incentives, information asymmetries, and contradictory motivations for academic entrepreneurs, organizations, and TTOs (Kenney and Patton, 2009). On the other hand, academic entrepreneurs benefit not only from the organization covering the costs of filing, renewing and defending a patent, but also from a better support infrastructure. This is because the prospect of additional revenue motivates organizations to invest into infrastructure to support technology commercialization (Baldini, 2009; Sellenthin, 2009).

It is straightforward to argue that organizational characteristics should matter more in strong organizational regimes. In this context, the effect of patenting norms is reinforced as legal norms complement existing social norms and introduce a second sanctioning mechanism into the organization (Elster, 1989; Meek et al., 2010). Then, pressures to seek patents not 
only emanate from the peer group, but also from legal authorities. Even in cases where such social norms are low or non-existing (Bercovitz and Feldman, 2008), strong regimes incentivize and entitle some actors within the organization, in particular the TTO, to patent employee inventions irrespective of inventor preferences (Kenney and Patton, 2009). A similar reasoning applies to organizational publication norms. Organizations high in such norms typically possess greater stocks of novel knowledge allowing academic entrepreneurs to produce more novel and patentable knowledge (Czarnitzki et al., 2009). However, given the additional obligations through legal norms, more of this knowledge is eventually patented in strong organizational regimes. Strong organizational regimes may also amplify the effect of organizational patenting capabilities. This is because academic entrepreneurs are more likely to patent if the organization does not only have a high success rate of patent applications, but also offers a supportive infrastructure, as is often characteristic of strong regimes (Baldini, 2009; Sellenthin, 2009). Thus, ceteris paribus,

Hypothesis 3a. In strong organizational regimes, organizational characteristics (as suggested in H2a-c) have stronger relations with academic entrepreneurs' patent propensity than founding team characteristics (as suggested in H1a-b).

Our arguments for the role of weak organizational regimes flow logically from the above: Since the reinforcing effect of additional legal norms is missing in weak regimes, founding team characteristics should play a stronger role for patenting decisions in this context. However, we expect organizational characteristics, as theorized in Hypotheses 2a - c, to be influential also in weak regimes but this influence should be smaller compared to strong regimes. Thus, ceteris paribus, 
Hypothesis 3b. In weak organizational regimes, founding team characteristics (as suggested in H1a-b) have stronger relations with academic entrepreneurs' patent propensity than organizational characteristics (as suggested in H1a-b).

\section{METHODS}

\section{Research Context}

Technology-based spin-offs from public universities and research organizations in Germany, such as Fraunhofer Society, Helmholtz Association, Leibniz Science Association, and Max-Planck Society, provide the setting of our study. These institutions are among the key players in the German public science sector (Krabel and Mueller, 2009:948 for details). Before 2002, German universities reflected 'weak organizational regimes’ because the socalled professorial privilege ('Hochschullehrerprivileg') gave academic employees the full ownership of inventions. However, in 2002, this right was abolished by a modification of the Employees’ Inventions Act (§42 ArbNErfG), empowering universities to commercialize their employees’ inventions in most cases. The reform was enacted in January 2002 and relevant for all inventions made after February 6, 2002 (§43ArbNErfG). TTOs and extra-university patent \& valorization agencies ('Patentverwertungsagenturen') were established to assist universities in patenting and commercializing patent rights. This relative recent regime change allows us to examine weak organizational regimes by sampling university spin-offs in the pre-2002 era. In turn, public research organizations represent 'strong organizational regimes' since they have been governed by the Employees’ Inventions Act of 1957 and were therefore not part of the legal reform of 2002 (Harhoff and Hoisl, 2007). ${ }^{6}$ Sampling from

\footnotetext{
${ }^{6}$ Two points are important to note. First, research organizations and universities have started to increasingly collaborate in the recent years. For instance, the new mission of Helmholtz Association explicitly includes initiating and expanding networks to universities (Helmholtz Association, 2015). This can lead to crossaffiliations, for instance where an academic from a research organization also holds an honorary university professorship or where a PhD student employed by a research organization is registered at a university as research organizations are not entitled to award PhDs in the German legislation. Second, although we model public research organizations as proxies for strong organizational regimes, there is notable variance in the patenting activities across these organizations. However, given that these are rather recent developments, we
} 
research organizations is beneficial for the purpose of our study because it is, compared to the alternative sampling from universities in the post-2002 era, more likely to show the long-term effects of this Bayh-Dole-like act.

\section{Sample and Procedure}

This study combines survey and patent data. Survey data came from face-to-face interviews with academic entrepreneurs that were conducted as part of a larger study on academic spin-offs. After assembling an initial list of 850 firms from TTOs, print media, and the internet, we called 524 randomly selected spin-offs to request interview appointments. In 2005 and 2006, trained interviewers conducted face-to-face interviews with those 288 spinoffs willing to participate. One founder per spin-off volunteered as interviewee on behalf of the founding team and also provided names and academic degrees of the co-founders. ${ }^{7}$ The interviewee had to be involved in the development of the spin-off's core technology and part of the founding team from the outset. We validated information on the founding team by searching the German commercial register ('Handelsregister'). To be considered for our sample, a spin-off had to meet the following criteria: (1) The business model was based on a technological invention developed by at least one founder, excluding, for instance, consulting firms. This restriction is important as our model seeks to explain decisions to patent, thereby assuming patentability of the core technology. (2) At least one founder was an academic employee, including doctoral students, post-docs and professors, in a public university or research organization at the time of founding. (3) The spin-off was headquartered in Germany.

propose that pre-2002 universities and public research organizations in Germany adequately reflect weak and strong organizational regimes, respectively.

${ }^{7}$ Key informant responses were found to be particular accurate for salient events, for small rather than large firms, and for respondents with high hierarchical positions and long tenure (Homburg et al., 2012). Our interviews with start-up founders may meet these requirements, so that we expect the reliability of the responses to be high. 
Patent data came from the database 'PATSTAT’ provided by the European Patent Office. We searched for patent applications within a six-year period around incorporation, which included the pre-founding phase (two full years prior to incorporation and the incorporation year), and the post-founding phase (the following three years). Data were also collected for 8 and 10-year periods. These time frames allowed us to examine $87 \%, 92 \%$, and $96 \%$ of all patent family applications, respectively, from ten years prior to incorporation up to six years after (Figure 1). Since there is no theory or empirical evidence suggesting one time period as optimal for our study, we estimated regression models for all three periods and based our inference on the average effect. We considered applications that were (1) based on a founder's invention and filed by the university or research organization, (2) filed by a founder, or (3) filed by the spin-off. Founders in Categories 1 and 2 were members of the university or research organization at the time of founding. However, the database contained no information on which of the patents in these categories were actually licensed back or used by the spin-off. We therefore inspected the content of the patents and included only those patents matching the spin-off's core technology. Database searches for popular names, such as ‘Müller’ or 'Schmidt’, occasionally produced excessive or ambiguous results. We then checked the content of the patents, the residence of the inventors and applicants, whether the founders’ university or research organization was listed as applicant and whether other founding team members were named as inventor or applicant. We excluded pre-founding patents co-filed by industry partners. These patents typically result from contract research or jobs in the industry and are often commercially exploited by the industry partner (Thursby et al., 2009).

Please insert Figure 1 about here 
The samples for weak and strong organizational regimes were matched in terms of technological fields and venture capital. This yielded a matched sample of 79 spin-offs from public universities and research organizations, respectively. Spin-offs originating in both types of organizations were excluded. The subsamples did not significantly differ in terms of founder and spin-off characteristics described below. Technological fields comprised software/simulation (39\%), biotechnology (29\%), photonics (8\%), microelectronics (6\%), microsystems (5\%) and others (13\%). The average venture had been in business for six years $(s d=2.40)$, had three founders ( $s d=1.59)$, and employed nine full-time equivalents $(s d=$ 14.69). Spin-offs were founded between 1992 and 2001 regarding universities and 1995 to 2005 regarding research organization. ${ }^{8}$ Overall, the 158 spin-offs originated in 50 universities and 66 research organizations. We accounted for the partly nested structure of the data in our analysis by using robust standard errors clustered at organizational level. About one half of the spin-offs had not filed patents in the six-year period (universities: 54\%; research organizations: 48\%). The average number of patent family applications was $3.32(s d=7.59)$ for universities and 5.27 ( $s d=13.69)$ for research organizations. One spin-off had filed an extraordinarily high number of 109 patents. According to content analysis, this case did not qualify as an outlier. Regression analyses without the case did not substantially alter the pattern of our regression results. We therefore decided not to exclude the case.

\section{Measures}

\section{Dependent Variables}

Patent propensity refers to the tendency of an individual or a group to seek patents for inventions. In line with the extant literature (e.g., Brouwer and Kleinknecht, 1999), we

\footnotetext{
${ }^{8}$ Some university spin-offs were founded in 2001, thus close to time when the modified Employees’ Inventions Act became effective. According to research by Dornbusch and Neuhäusler (2015), the prospect of the change, in particular the prospect of having to share patent revenues with the university, might have discouraged academic patenting already starting in 1999. However, spin-offs in our sample founded after 1998 do not significantly differ in their patenting activity from spin-offs created before that $(F=.16, p>.10)$.
} 
measured it as the number of patent family applications. A patent family comprises all patent applications based on the same invention in different jurisdictions. Grouping patent applications into families avoids redundant counts by considering the same invention only once in our data (Lettl et al., 2009). This measure captures the extent to which academic entrepreneurs opt for patents. We constructed the variables for the founding team and spin-off for the abovementioned 6-, 8- and 10-year periods.

\section{Independent Variables}

We derived an own measure for expert knowledge because our research design required shorter and less complex scales than existing ones. The scale describes the extent to which the founders were experts in their fields and knowledge about the core technology was unavailable via external sources. It was measured-like all other items, unless stated otherwise—on a 7-point Likert-scale (1 = "I completely disagree” to 7 = "I completely agree”) with three reflective items (alpha $=.71$ ). The items emphasize the related aspects of expert status and knowledge scarcity—-the building blocks of our definition of expert knowledge—differently: One item ("Members of the founding team were considerably involved in technological breakthroughs in my company’s technological field.”) highlights the prior, whereas two other, reverse coded items highlight the latter ("Knowledge about the operational principles of my company’s core technology was widely disseminated in the scientific community.”, “Competitors were able to very quickly learn about the core technology from public sources (books, journals, internet, etc.) to the point of being able to implement it.”). Confirming criterion validity, the three-item measure is significantly correlated with measures for the popularity of the core technology $(r=-.22, p<.001)$, market potential $(r=.20, p<.05)$, and radicalness of patent family applications $(r=.26, p<.05)$.

To operationalize dimensions of entrepreneurial orientation, we built upon the established Covin and Slevin (1989) scale. Because the original scale referred to established 
firms, we adjusted some items to the context of spin-offs. For instance, the item "[my firm] typically initiates actions which competitors then respond to" was replaced by the item "our company undertakes great efforts to find new applications for our core technologies and to open new markets for our existing products/services.” As the dimensionality of the construct is an area of ongoing debate (Rauch et al., 2009), we factor-analyzed the items to confirm the original three-factor solution. After dropping items with a factor loading of less than .40, a common rule of thumb (e.g., Richard et al., 2004), the three dimensions innovativeness (2 items), proactiveness (3 items), and risk-taking (2 items) emerged, with alpha levels of .75, .64 , and .70, respectively. Although the Average Variance Extracted of proactiveness (AVE = .44) was lower than the desired .50, Composite Reliability exceeded the recommended threshold of .60. Moreover, a test recommended by Fornell and Larcker (1981) confirmed discriminant validity of our scales. The sum of the three dimensions forms the final measure for entrepreneurial orientation.

Following Calderini et al. (2007), we operationalized organizational patenting norms as the total number of patents per researcher that the organization has filed within a five-year period prior to the founding phase. Patent data were extracted from the PATSTAT database. Information on the number of researchers came from the German Federal Statistical Office. Organizational patenting capabilities were measured as the share of granted patents from all university patent applications within the five-year period. In eight cases where the spin-off originated from two or three organizations, we averaged the three organizational variables. To measure organizational publication norms, we counted publications per researcher from the ISI Web of Science. Our search included journal articles published within five full years prior to the pre-founding phase. Although ISI data is known for potential biases, e.g., overweighting journals published in English or disciplines that prefer journals to other research outlets (Crespi and Geuna, 2008), it belongs to the most widely used sources (e.g., Azoulay et al., 2007; Calderini et al., 2007). 


\section{Control Variables}

To isolate the effect of our predictor variables, we considered several control variables. An organizational focus on applied research can lead scientists to strive for more commercially-oriented discoveries and align their research agenda to the needs of the industry (Landry et al., 2007), possibly yielding more patentable outcomes. This variable was captured as the value of industry funding per academic employee (in 100,000 Euros), a measure similar to Di Gregorio and Shane (2003). We gathered data from the Federal Statistical Office (Series 11-4.3.2, e.g., Statistisches Bundesamt, 2010). To measure patent effectiveness, an important driver of patenting, patent attorneys rated the degree to which patents reliably protect against imitation and grant enforceable rights in several technological fields (7-point Likert-scale; 1 = "very low effectiveness", 7 = "very high effectiveness"). These fields were also used to categorize spin-offs and included biotechnology, microsystems, microelectronics, molecular electronics, nanotechnology, new materials, photonics, production techniques, and software/simulation. We sent a standardized questionnaire to 2,417 individuals, listed in the directory of German patent attorneys. Of those, 190 usable questionnaires were returned (8\%). On average, the respondents had worked for 9.59 years $(s d=8.82)$ as patent attorneys and for 14.87 years $(s d=10.33)$ in patent-related fields. An intraclass correlation of .99 indicated high inter-rater agreement. As each spin-off in our sample was active in only one technological field, we assigned the rating as our measure for patent effectiveness. Values ranged from an average rating of $3.63(s d=1.57)$ for production techniques to $5.84(s d=$ 1.10) for new materials.

Technological uncertainty was captured with three reflective items conceptually based on the work of Bhide (1994) and Shane (2004b: 186-190). A significant correlation with a theoretically related measure of market uncertainty $(r=.32, p<.001)$ confirms criterion validity. The measure is reliable at an alpha of .77. Patents are conducive to venture capital 
investments, as they secure value of the firm and signal technological quality (Wright et al., 2006). The same rationale might drive venture capitalists on the board of new ventures to encourage patenting. We measure it with a dummy $(1=$ "at least one venture capitalist holds stakes in firm equity”, 0 = else). Firms high in $R \& D$ intensity are more likely to develop patentable breakthrough innovation (Arundel and Kabla, 1998). We measure R\&D intensity as the ratio of $R \& D$ employees and scientific founders to total employees and all founders. Larger spin-offs possess more resources to develop patentable inventions. We therefore controlled for the number of R\&D employees including scientific founders. Prior research has linked patenting activity to publication performance (Baldini, 2009; Calderini et al., 2007; D’Este and Perkmann, 2011; Landry et al., 2007), leading us to include the number of publications by the founding team until the founding year as another control variable. Moreover, the theory of planned behavior suggests past behavior as a strong predictor of future behavior (Ajzen, 1991). Previous patenting does not only reflect a preference for and experience in patenting (Baldini, 2009; Sellenthin, 2009), it also be a rough proxy for prior patenting costs and efforts. We thus controlled for the number of previous patents filed by founding team members prior to the founding phase.

\section{RESULTS}

Tables 1 and 2 provide the descriptive statistics and correlation matrix for universities and research organizations, respectively. Table 3 displays the regression results. Since our dependent variables are counts of scores, we used negative binomial regression to estimate our models. ${ }^{9}$ Calculations of the variance inflation factor (VIF) revealed no serious multicollinearity problems (VIF < 3.70).

\footnotetext{
${ }^{9}$ Poisson regression and its generalized form, the negative binomial regression, are two ways of dealing with count data (Hausman et al., 1984). The first model assumes that the conditional mean of the outcome is equal to the conditional variance. According to a likelihood-ratio test for overdispersion, the conditional variance of our dependent variable was significantly greater than the conditional mean, violating this assumption. We therefore used negative binomial regression which assumes a gamma distribution for the conditional mean,
} 
Our first set of hypotheses examined founding team characteristics. Hypothesis 1a suggested a positive influence of expert knowledge on patent propensity. The effect was positive and significant only in weak organizational regimes as represented by universities (Model 4, $b=.39, p<.05$ ). Hypothesis 1a thus received partial support. Similarly, entrepreneurial orientation was positively linked to patent propensity (Model 4, $b=.20$, $p<$ .05 ) only in weak organizational regimes so that also Hypothesis $1 \mathrm{~b}$ received partial support. A second set of hypotheses illuminated organizational characteristics. In line with Hypothesis 2a, organizational patenting norms were positively related to patent propensity (Model 8, $b=$ 3.46, $p<.05$ ), but only in strong organizational regimes as represented by research organizations. Hypotheses $2 \mathrm{~b}$ and 2c linked patent propensity to organizational patenting capabilities and organizational publication norms, respectively. Both hypotheses received no support (Models 4 and 8). According to a final set of hypotheses, the strengths of the above effects vary with the organizational regime. Hypothesis 3a predicted a stronger influence of organizational characteristics in strong organizational regimes. We used the seemingly unrelated estimation (SUEST) algorithm in Stata 11 to examine whether coefficients significantly differed across models. The results provide weak support for Hypothesis 3a: in strong organizational regimes, organizational characteristics had stronger positive relationships with patent propensity $\left(X^{2}=4.93, p<.10\right)$. Supporting Hypothesis 3b, founding team characteristics had stronger relationships with patent propensity in weak organizational regimes $\left(X^{2}=9.04, p<.05\right)$. 
There are a number of notable findings for our control variables. Organizational focus on applied research was negatively and (weakly) significantly related to patent propensity. Possibly, such a focus coincides with more contract research within the organization so that also academic entrepreneurs 'sell' more of their intellectual property to the industry rather than claiming it for their ventures. Moreover, R\&D intensity had significant effects only in weak organizational regimes. As one explanation, in weak regimes, academic entrepreneurs might transfer technological intermediates at an early stage, in order to finalize R\&D within their ventures. In contrast, the number of previous patents was significantly related to patent propensity only in strong regimes, suggesting that an organizational emphasis on patenting might have also influenced patenting behavior of academic entrepreneurs in the past. Interestingly, patent effectiveness had no significant effect in strong regimes, for which two alternative explanations could be proposed. First, strong organizational regimes (mis-)lead academic entrepreneurs, for instance via organizational norms, routines, and the influence of the TTO, to also seek patents in fields offering only weak protection. Thus, in this context rigid organizational practices tend to emerge that can disregard founders’ interests. Second and supported by additional analyses, the variable 'venture capital' fully mediates the relationship between patent effectiveness and number of patent family applications in strong regimes. ${ }^{10}$ Therefore patent effectiveness is no longer statistically significant when controlling for the mediator 'venture capital'.

\footnotetext{
${ }^{10}$ Our analyses suggest that the conditions for a full mediation were met (Baron and Kenny, 1986): (1) The independent variable 'patent effectiveness' was significantly related to the mediator 'venture capital' $(b=.76$, $p<.05$; average effects reported); (2) when tested without the latter, patent effectiveness was significantly related to the dependent variable 'patent propensity' $(b=1.60, p<.01)$; (3) when tested together, venture capital $(b=1.40, p<.01)$ but not patent effectiveness $(b=1.37, n s)$ was significantly related to patent propensity. There are also theoretical arguments for these relationships: Fields with strong patent protection are more attractive for venture capitalists as they promise greater returns (Reitzig, 2003). Venture capitalists may encourage more intensive patenting to create patent fences, to convert tacit founder knowledge into knowledge assets of the spin-off (Kim and Marschke, 2005) or to expand to international markets. Finally, venture capitalists may drive patenting only in strong regimes as this context is conducive to long-term and trust-based relationships with TTOs, which reduces transaction costs and facilitates patenting irrespective of founder preferences.
} 


\section{DISCUSSION}

In this study, we explored why academic entrepreneurs seek patents in weak vis-à-vis strong organizational regimes. Their decision is far from being straightforward: Some scholars proposed that spin-offs are dependent on patentability considerations (Lowe, 1993; Shane, 2001) and highlighted many advantages of patenting for spin-offs (e.g., Harter, 1994; Kaiser, 2009). Other scholars pointed to the many disadvantages and risks involved, in particular for spin-offs (Arundel, 2001; Lanjouw and Schankerman, 2004). Specifically, we argued that founding team characteristics-expert knowledge (Hypothesis 1a) and entrepreneurial orientation (Hypothesis 1b)—as well as organizational characteristics— patenting norms (Hypothesis 2a), patenting capabilities (Hypothesis 2b), and publication norms (Hypothesis 2c)—increase the patent propensity of academic entrepreneurs. Moreover, organizational characteristics prevail, as we further propose, in strong organizational regimes (Hypothesis 3a), whereas founding team characteristics prevail in weak organizational regimes (Hypothesis 3b).

A first key insight of this study is that in strong organizational regimes, social norms seem to be a main driving force behind patenting by academic entrepreneurs. In this context, organizational patenting norms were the only of our hypothesized variables that was significantly related to patent propensity (Hypothesis 2a). Prior research has long documented the role of norms for scientists' engagement in patenting (e.g., Bercovitz and Feldman, 2008). Our study does not only examine the neglected subgroup of academic entrepreneurs, it also suggests that besides norms several theoretically important aspects do not matter in strong organizational regimes. For instance, the 'organizational success rate' in patenting, in terms of organizational patenting capabilities (Hypothesis 2b), played no significant role in this context, although it is, on average, higher than in weak regimes $(F>80.14, p<.001)$. Moreover, the strong influence of organizational patenting norms could lead to an overreliance on patents vis-à-vis alternative protection mechanisms often preferred by smaller 
firms (Arundel, 2001; Leiponen and Byma, 2009; Markman et al., 2005). This resembles Sampat's (2006: 783) observation: “The importance of patents and licensing for development and commercialization of university inventions was not well understood during the BayhDole hearings and is not well understood today. Universities can patent any inventions developed by their faculty members and certainly do not limit their patenting to cases where commercialization would go forward even with no patenting and licensing.” Taken together, strong organizational regimes seem to be conducive to organizations creating rigid patenting procedures, which tend to ignore other critical interests in patenting.

A second key insight is that in weak organizational regimes, academic entrepreneurs higher in expert knowledge (Hypothesis 1a) and entrepreneurial orientation (Hypothesis 1b) seek patents more extensively. Prior research has often used proxies, such as holding a doctorate (Dietz and Bozeman, 2005), to measure endowments with human capital. This study captured levels of expert knowledge more directly and demonstrated that it is related to patent propensity above and beyond publishing and patenting experience. Moreover, although theory suggests attitudes as critical antecedent of human behavior (Ajzen, 1991), prior research has neglected attitudinal variables to explain why scientists vary in their tendency to disclose and patent. This article links a distinct attitudinal variable, namely entrepreneurial orientation, to patent propensity, both theoretically and empirically. The findings highlight the importance of considering attitudes in patenting research, at least in the context of weak organizational regimes.

The finding that expert knowledge and entrepreneurial orientation had no significant effect in strong organizational regimes exceeded our expectations, as formulated in Hypothesis 3a. Prior research has already suggested that strong organizational regimes create incentives for universities, in particular TTO managers, to maximize short-term income from technology licensing (Kenney and Patton, 2009) and that licensing-for-cash is the most prevalent technology transfer mechanism (Markman et al., 2005). According to our findings, 
founder preferences are ignored in this context. This seems to contradict observations that inventor cooperation is crucial to successfully commercialize a technology and that the inventor may therefore influence patenting decisions (e.g., Agrawal, 2006). To reconcile, even patent-averse founding teams might have initially engaged in symbolic patenting to satisfy the TTO and remain in good standing with the organization (Bercovitz and Feldman, 2008). The initial patents might have attracted venture capitalists or R\&D alliance partners (Hertzfeld et al., 2006), which resulted in more patenting. Possibly, the founders also realized later that an effective protection required more than a single patent and started to build patent fences.

In addition, this study informs the literature on patenting by being the first one (we know of) to track when and how extensively academic entrepreneurs seek patents. In this line of research, defining an appropriate time frame to track pre-founding patents for the spin-off is often a challenging task. In other words, how early do academic entrepreneurs start to patent in preparation of their spin-offs? Our data provides a first orientation by suggesting that $87 \%$ to $96 \%$ of patenting activity takes place within a three to five-year window around incorporation. Moreover, about one half (52\% for universities and 43\% for research organizations) of the technology-based spin-offs has not filed patents in the ten-year window. This is surprising for scholars who consider patents as the pathway to establish competitive advantage for spin-offs (e.g., Lowe, 1993; Shane, 2001). It seems to confirm scholars who argued for the efficacy of alternative appropriation mechanisms, in particular in a start-up context (e.g., Arundel, 2001; Lanjouw and Schankerman, 2004).

Finally, our overall findings, in particular for the effect of patent effectiveness, warrant further discussion about the role of TTOs in strong organizational regimes. In one interpretation of the findings, patenting also takes place in areas where patents offer weak protection and rigid organizational procedures overrule interests of founders. This is consistent with views of the TTO as "risk-averse bureaucracies focused on short-term revenue maximization” (Kenney and Patton, 2009: 1412), having “an overemphasis on royalty income 
and an underemphasis on entrepreneurship” (Markman et al., 2005: 241). Similarly, in organizations with independently funded TTOs that face greater pressures to generate revenues, scientists were found to avoid disclosing their inventions (Zibin et al., 2011). According to other studies, European TTOs lack critical business skills compared to their US counterparts (Chapple et al., 2005; Conti and Gaule, 2011). However, in another interpretation, the effect of patent effectiveness on patenting flows via venture capitalists. This implies a positive role of TTOs as boundary spanners to the wider business environment. Kenney and Patton (2009) make a similar point, when suggesting that TTOs could have advantages in negotiating with outside firms in terms of institutional power and experience. While the question of whether TTOs support or hinder spin-offs through their IP policies cannot be answered on base of our data, our findings document a tendency towards comprehensive patenting to an extent that founder interests may be ignored.

\section{Limitations and future research}

Our study is not without limitations. First, sampling solely from organizations in Germany may yield results that are mostly generalizable to this context. Country differences, such as variations in jurisdiction, culture, and industry structure, might generate different conditions for patenting. While we have no a priori reason to believe that the findings would fail to apply to other country settings, this study addressed only one setting. Second, we used research organizations to proxy strong organizational regimes because they are likely to reflect the long-term consequences of Bayh-Dole-like acts, at least in the German context. More research into the short-run consequences is needed, in particular on how such legal reforms transformed universities and how this affected the rationales and scope of patenting by academic entrepreneurs. Third, we have focused on theoretically important organizational and founding team characteristics, warranting more research on other determinants of patenting in the context of our study. Fourth, our focus on patents led us to neglect alternative 
appropriation mechanisms, such as lead-time advantage, secrecy, and complexity (Arundel, 2001). Future research could therefore explore how often, in what combinations and with what success academic entrepreneurs employ these mechanisms. Finally, according to our findings, the shift from weak to strong organizational regimes has led academic entrepreneurs to seek patent for extrinsic rather than intrinsic motivations. Patenting might be more symbolic than substantial in strong regimes. For future studies, this raises the interesting question of how the quality of patents filed in both regimes differs and secures competitive advantage in both scenarios and what role the TTO plays in this milieu.

\section{Theoretical contributions}

This study has important implications for the current literature. One stream in the literature has focused on how legislative reforms affected technology transfer and innovation within a country (e.g., Sampat, 2006). A central finding is that university patenting has not changed in general, but in specific fields and universities (e.g., Henderson et al., 1998; Shane, 2004a). Only recently, scholars started to discuss implications for academic entrepreneurship. Employer-ownership models were criticized for creating conditions-ineffective incentives, information asymmetry, and contradictory motivations for key stakeholders - that are not conducive to academic entrepreneurship (Kenney and Patton, 2009). Our study contributes to this line of work by providing theoretical and empirical insights into patenting rationales under different ownership regimes. In particular, our results indicate how much organizations governed under an employer-ownership model differ from other organizations in the patenting rationales of academic entrepreneurs. In strong organizational regimes, organizational norms became a key driving force, whereas more intrinsic motivation, as arising from expert knowledge and entrepreneurial orientation, were not relevant any more. It is not surprising (and has been proposed in Hypothesis 3a) that organizations having property rights in employee inventions exert more influence on patenting decisions. However, our findings 
suggest that, in the context of our study, a residual, informal influence of the inventor may be low and patenting can become an organizational routine.

The literature also reported that revenue opportunities created by employer-ownership models led organizations to create infrastructures to support patenting (Baldini, 2009; Sellenthin, 2009). However, to date, we lack knowledge about whether academic entrepreneurs are ‘pushed’ into patenting by an organizational norm or ‘pulled’ by the prospect of superior patenting capabilities and support on part of the organization. This study disentangled both influences by separately examining organizational patenting norms and organizational patenting capabilities. The latter reflects those aspects of the support infrastructure allowing the organization to successfully file a higher share of patents. Our findings add to the literature by showing that the culture-explanation rather than the capabilities-explanation seems to hold. In addition, our study allows to speculate about how the implementation of legal reforms affected social norms in terms of organizational patenting norms. In this study, patenting norms and previous patenting by the founders were effective in strong, but not weak organizational regimes. This might indicate that legal reforms stimulated the evolution of social norms as drivers of patenting and that academic entrepreneurs comply with these norms in the long run.

Our findings for founding team characteristics add to the wider literature on patenting and invention disclosure. Combining hard data on patenting with perceptual data of founders allowed us to consider patenting rationales that were relatively neglected in the past. Prior work has measured endowments with human capital using proxies, such as holding a doctorate (Dietz and Bozeman, 2005), years after completing PhD (Landry et al., 2007), number and impact of previous publications (Baldini, 2009; Carayol, 2007), and having the rank of full professor (Bercovitz and Feldman, 2008). Our study captured human capital, in terms of levels of expert knowledge, more directly and demonstrated that it is related to patent propensity above and beyond publishing and patenting experience. It thereby disentangled 
stocks of knowledge from its manifestation in patents and/or publications. ${ }^{11}$ Moreover, our findings for entrepreneurial orientation suggest that considering attitudinal variables is important for understanding patenting rationales, at least in a weak organizational regime. The concept may also provide interesting insights into other forms of behavior because it allows capturing variance in the self-concept of academic entrepreneurs between the polar forms of academic and entrepreneur.

The study shed more light on the link between patenting and publishing. The publishing-patenting relationship is well explored for the individual scientist (e.g., Calderini et al., 2007), but rarely at the organizational level (Baldini, 2009; Carayol and Matt, 2004). This study is one of the first to examine the effect of university publication norms and academic entrepreneurs' patenting, while controlling for previous publishing on part of the founding team. The findings indicate that both publication variables not significantly related to the tendency of academic entrepreneurs to seek patents.

\section{Practical implications}

The results have at least two straightforward implications for technology transfer policies. First, our findings suggest that organizational norms lead academic entrepreneurs to patent, without respect to the organizational capability to successfully navigate through the application process. This reminds policy makers at universities and research organizations of a particular risk for academic entrepreneurs that may even increase with efforts to reinforce an organization's intellectual property rights: Filing patents that are eventually not granted or have low quality, thereby wasting valuable resources and disclosing critical knowledge. University administrations that lack resources and competences to effectively patent might

\footnotetext{
${ }^{11}$ While expert knowledge of inventors is likely to motivate patenting by academic entrepreneurs and established firms alike, the underlying mechanisms may differ. Expert knowledge gives academic entrepreneurs the chance, as we argue, to mix patent strategies with other IP protection strategies, such as lead time. For established firms, it can involve a risk of inventor mobility and patenting becomes a defense against knowledge losses by employees joining a competitor or starting their own business (Kim and Marschke, 2005).
} 
therefore profit more from considering alternative ways of claiming their ownership in inventions, for instance, by taking equity in the spin-off. The literature has highlighted the specific advantages of inventor-ownership models, for instance resolving conflicts of interest (Kenney and Patton, 2009), and provided examples of their success implementation (Kenney and Patton, 2011). Some of the most successful universities in technology transfer still sustain an intellectual property (IP) policy where full ownership of IP rests with the creator, allowing faculty to freely commercialize their ideas (Bramwell and Wolfe, 2008).

Second, our findings might sensitize university administrations for academic entrepreneurs’ rationales in patenting. Such knowledge can help align technology transfer policies to spin-offs’ specific needs, in order to create a win-win situation between founders and organization. For instance, our findings suggest that, when expert knowledge and entrepreneurial orientation are high, academic entrepreneurs appreciate patents more and are thus more likely to fully support the patenting process. These insights also encourage policy makers and university administrations to critically reflect whether organizational and spin-off interests in patenting diverge. If organizational policies and culture lead academic entrepreneurs to adopt a patenting strategy (be it symbolic or substantial), alternative and possibly more effective protection strategies, such as secrecy, are neglected.

\section{REFERENCES}

Agrawal, A., Henderson, R., 2002. Putting patents in context: Exploring knowledge transfer from MIT. Management Science 48 (1), 44-60.

Agrawal, A., 2006. Engaging the inventor: Exploring licensing strategies for university inventions and the role of latent knowledge. Strategic Management Journal 27 (1), 63-79.

Ajzen, I., 1991. The theory of planned behavior. Organizational Behavior and Human Decision Processes 50 (2), 179-211.

Aldridge, T., Audretsch, D.B., 2010. Does policy influence the commercialization route? Evidence from national institutes of health funded scientists. Research Policy 39 (5), 583-588.

APE-INV Project, 2009. Academic patenting in Europe. http://www.esf-ape-inv.eu, 2015-09-04.

Armitage, C.J., Conner, M., 2001. Efficacy of the theory of planned behaviour: A meta-analytic review. British Journal of Social Psychology 40 (4), 471-499. 
Arundel, A., Kabla, I., 1998. What percentage of innovations are patented? Empirical estimates for European firms. Research Policy 27 (2), 127-141.

Arundel, A., 2001. The relative effectiveness of patents and secrecy for appropriation. Research Policy 30 (4), 611-624.

Atuahene-Gima, K., Ko, A., 2001. An empirical investigation of the effect of market orientation and entrepreneurship orientation alignment on product innovation. Organization Science 12 (1), 54-74.

Azoulay, P., Ding, W., Stuart, T., 2007. The determinants of faculty patenting behavior: Demographics or opportunities? Journal of Economic Behavior \& Organization 63 (4), 599-623.

Azoulay, P., Ding, W., Stuart, T., 2009. The impact of academic patenting on the rate, quality and direction of (public) research output. The Journal of Industrial Economics 57 (4), 637-676.

Baldini, N., 2009. Implementing Bayh-Dole-like laws: Faculty problems and their impact on university patenting activity. Research Policy 38 (8), 1217-1224.

Baron, R.M., Kenny, D.A., 1986. The moderator-mediator variable distinction in social psychological research: Conceptual, strategic, and statistical considerations. Journal of Personality and Social Psychology 51 (6), 11731182.

Bercovitz, J., Feldman, M., 2008. Academic entrepreneurs: Organizational change at the individual level. Organization Science 19 (1), 69-89.

Bhide, A., 1994. How entrepreneurs craft strategies that work. Harvard Business Review 72 (2), 150-161.

Blind, K., Edler, J., Frietsch, R., Schmoch, U., 2006. Motives to patent: Empirical evidence from Germany. Research Policy 35 (5), 655-672.

Bramwell, A., Wolfe, D.A., 2008. Universities and regional economic development: The entrepreneurial University of Waterloo. Research Policy 37 (8), 1175-1187.

Brouwer, E., Kleinknecht, A., 1999. Innovative output, and a firm's propensity to patent: An exploration of CIS micro data. Research Policy 28 (6), 615-624.

Bryant, P.T., 2014. Imprinting by design: The microfoundations of entrepreneurial adaptation. Entrepreneurship: Theory \& Practice 38 (5), 1081-1102.

Calderini, M., Franzoni, C., Vezzulli, A., 2007. If star scientists do not patent: The effect of productivity, basicness and impact on the decision to patent in the academic world. Research Policy 36 (3), 303-319.

Carayol, N., Matt, M., 2004. Does research organization influence academic production?: Laboratory level evidence from a large European university. Research Policy 33 (8), 1081-1102.

Carayol, N., 2007. Academic incentives, research organization, and patenting at a large French university. Economics of Innovation \& New Technology 16 (2), 119-138.

Chapple, W., Lockett, A., Siegel, D., Wright, M., 2005. Assessing the relative performance of U.K. University technology transfer offices: Parametric and non-parametric evidence. Research Policy 34 (3), 369-384.

Cohen, W.M., Nelson, R.R., Walsh, J.P., 2002. Links and impacts: The influence of public research on industrial R\&D. Management Science 48 (1), 1-23.

Conti, A., Gaule, P., 2011. Is the US outperforming Europe in university technology licensing? A new perspective on the European paradox. Research Policy 40 (1), 123-135.

Covin, J.G., Slevin, D.P., 1989. Strategic management of small firms in hostile and benign environments. Strategic Management Journal 10 (1), 75-87.

Crespi, G., D’Este, P., Fontana, R., Geuna, A., 2011. The impact of academic patenting on university research and its transfer. Research Policy 40 (1), 55-68. 
Crespi, G.A., Geuna, A., 2008. An empirical study of scientific production: A cross country analysis, 19812002. Research Policy 37 (4), 565-579.

Czarnitzki, D., Glänzel, W., Hussinger, K., 2009. Heterogeneity of patenting activity and its implications for scientific research. Research Policy 38 (1), 26-34.

D’Este, P., Perkmann, M., 2011. Why do academics engage with industry? The entrepreneurial university and individual motivations. The Journal of Technology Transfer 36 (3), 316-339.

Della Malva, A., Lissoni, F., Llerena, P., 2013. Institutional change and academic patenting: French universities and the innovation act of 1999. Journal of Evolutionary Economics 23 (1), 211-239.

Di Gregorio, D., Shane, S., 2003. Why do some universities generate more start-ups than others? Research Policy 32 (2), 209-227.

Dietz, J.S., Bozeman, B., 2005. Academic careers, patents, and productivity industry experience as scientific and technical human capital. Research Policy 34 (3), 349-367.

Doutriaux, J., 1987. Growth pattern of academic entrepreneurial firms. Journal of Business Venturing 2 (4), 285.

Elster, J., 1989. Social norms and economic theory. Journal of Economic Perspectives 3 (4), 99-117.

Fabrizio, K.R., Di Minin, A., 2008. Commercializing the laboratory: Faculty patenting and the open science environment. Research Policy 37 (5), 914-931.

Fornell, C., Larcker, D.F., 1981. Evaluating structural equation models with unobservable variables and measurement error. Journal of Marketing Research 18 (1), 39-50.

Geuna, A., Nesta, L.J.J., 2006. University patenting and its effects on academic research: The emerging European evidence. Research Policy 35 (6), 790-807.

Harhoff, D., Hoisl, K., 2007. Institutionalized incentives for ingenuity - patent value and the German Employees' Inventions Act. Research Policy 36 (8), 1143-1162.

Harter, J.F.R., 1994. The propensity to patent with differentiated products. Southern Economic Journal 61 (1), 195-201.

Hatch, N.W., Dyer, J.H., 2004. Human capital and learning as a source of sustainable competitive advantage. Strategic Management Journal 25 (12), 1155-1178.

Hausman, J., Hall, B.H., Griliches, Z., 1984. Econometric models for count data with an application to the patents-R\&D relationship. Econometrica 52 (4), 909-938.

Helmholtz Association, 2015. Assuring quality, instilling impetus. http://www.helmholtz.de/en/about_us/initiating_and_networking/, 2015-09-04.

Henderson, R., Jaffe, A.B., Trajtenberg, M., 1998. Universities as a source of commercial technology: A detailed analysis of university patenting. Review of Economics \& Statistics 80 (1), 119-132.

Hertzfeld, H.R., Link, A.N., Vonortas, N.S., 2006. Intellectual property protection mechanisms in research partnerships. Research Policy 35 (6), 825-838.

Hoang, H., Gimeno, J., 2010. Becoming a founder: How founder role identity affects entrepreneurial transitions and persistence in founding. Journal of Business Venturing 25 (1), 41-53.

Homburg, C., Klarmann, M., Reimann, M., Schilke, O., 2012. What drives key informant accuracy? Journal of Marketing Research 49 (4), 594-608.

Jain, S., George, G., Maltarich, M., 2009. Academics or entrepreneurs? Investigating role identity modification of university scientists involved in commercialization activity. Research Policy 38 (6), 922-935. 
Jensen, R., Thursby, M., 2001. Proofs and prototypes for sale: The licensing of university inventions. American Economic Review 91 (1), 240-259.

Jensen, R.A., Thursby, J.G., Thursby, M.C., 2003. Disclosure and licensing of university inventions: 'the best we can do with the $s^{* *}$ t we get to work with'. International Journal of Industrial Organization 21 (9), 1271-1300.

Kaiser, U., 2009. Patents and profit rates. Economics Letters 104 (2), 79-80.

Kandori, M., 1992. Social norms and community enforcement. Review of Economic Studies 59 (1), 63-80.

Kenney, M., Patton, D., 2009. Reconsidering the Bayh-Dole act and the current university invention ownership model. Research Policy 38 (9), 1407-1422.

Kenney, M., Patton, D., 2011. Does inventor ownership encourage university research-derived entrepreneurship? A six university comparison. Research Policy 40 (8), 1100-1112.

Kim, J., Marschke, G., 2005. Labor mobility of scientists, technological diffusion, and the firm's patenting decision. RAND Journal of Economics 36 (2), 298-317.

Krabel, S., Mueller, P., 2009. What drives scientists to start their own company?: An empirical investigation of Max Planck Society scientists. Research Policy 38 (6), 947-956.

Kultti, K., Takalo, T., Toikka, J., 2007. Secrecy versus patenting. RAND Journal of Economics 38 (1), 22-42.

Landry, R., Amara, N., Saïhi, M., 2007. Patenting and spin-off creation by Canadian researchers in engineering and life sciences. The Journal of Technology Transfer 32 (3), 217-249.

Lanjouw, J.O., Schankerman, M., 2004. Protecting intellectual property rights: Are small firms handicapped? Journal of Law \& Economics 47 (1), 45-74.

Larsen, M.T., 2011. The implications of academic enterprise for public science: An overview of the empirical evidence. Research Policy 40 (1), 6-19.

Leiponen, A., Byma, J., 2009. If you cannot block, you better run: Small firms, cooperative innovation, and appropriation strategies. Research Policy 38 (9), 1478-1488.

Lettl, C., Rost, K., von Wartburg, I., 2009. Why are some independent inventors heroes and others hobbyists? The moderating role of technological diversity and specialization. Research Policy 38 (2), 243-254.

Levitas, E., McFadyen, M.A., 2009. Managing liquidity in research-intensive firms: Signaling and cash flow effects of patents and alliance activities. Strategic Management Journal 30 (6), 659-678.

Link, A., Ruhm, C., 2011. Public knowledge, private knowledge: The intellectual capital of entrepreneurs. Small Business Economics 36 (1), 1-14.

Lissoni, F., Llerena, P., McKelvey, M., Sanditov, B., 2008. Academic patenting in Europe: New evidence from the keins database. Research Evaluation 17 (2), 87-102.

Lissoni, F., 2012. Academic patenting in Europe: An overview of recent research and new perspectives. World Patent Information 34 (3), 197-205.

Louis, K.S., Blumenthal, D., Gluck, M.E., Stoto, M.A., 1989. Entrepreneurs in academe: An exploration of behaviors among life scientists. Administrative Science Quarterly 34 (1), 110-131.

Lowe, J., 1993. Commercialization of university research: A policy perspective. Technology Analysis \& Strategic Management 5 (1), 27-37.

Lumpkin, G.T., Dess, G.G., 1996. Clarifying the entrepreneurial orientation construct and linking it to performance. Academy of Management Review 21 (1), 135-172.

Mann, R.J., Sager, T.W., 2007. Patents, venture capital, and software start-ups. Research Policy 36 (2), $193-208$. 
Mansfield, E., 1986. Patents and innovation: An empirical study. Management Science 32 (2), 173-181.

Markman, G.D., Phan, P.H., Balkin, D.B., Gianiodis, P.T., 2005. Entrepreneurship and university-based technology transfer. Journal of Business Venturing 20 (2), 241-263.

McMullen, J.S., Shepherd, D.A., 2006. Entrepreneurial action and the role of uncertainty in the theory of the entrepreneur. The Academy of Management Review 31 (1), 132-152.

Meek, W.R., Pacheco, D.F., York, J.G., 2010. The impact of social norms on entrepreneurial action: Evidence from the environmental entrepreneurship context. Journal of Business Venturing 25 (5), 493-509.

Meyer, M., 2006. Are patenting scientists the better scholars?: An exploratory comparison of inventor-authors with their non-inventing peers in nano-science and technology. Research Policy 35 (10), 1646-1662.

Miller, D., Friesen, P.H., 1983. Strategy-making and environment: The third link. Strategic Management Journal 4 (3), 221-235.

Mowery, D.C., Nelson, R.R., Sampat, B.N., Ziedonis, A.A., 2001. The growth of patenting and licensing by the U.S. Universities: An assessment of the effects of the Bayh-Dole act of 1980. Research Policy 30 (1), 99-119.

Mowery, D.C., Sampat, B.N., Ziedonis, A.A., 2002. Learning to patent: Institutional experience, learning, and the characteristics of U.S. University patents after the Bayh-Dole act, 1981-1992. Management Science 48 (1), 73-89.

Mowery, D.C., Ziedonis, A.A., 2002. Academic patent quality and quantity before and after the Bayh-Dole act in the United States. Research Policy 31 (3), 399-418.

Nicolaou, N., Birley, S., 2003. Academic networks in a trichotomous categorisation of university spinouts. Journal of Business Venturing 18 (3), 333-359.

Owen-Smith, J., Powell, W.W., 2001. To patent or not: Faculty decisions and institutional success at technology transfer. The Journal of Technology Transfer 26 (1), 99-114.

Owen-Smith, J., Powell, W.W., 2003. The expanding role of university patenting in the life sciences: Assessing the importance of experience and connectivity. Research Policy 32 (9), 1695-1711.

Rauch, A., Wiklund, J., Lumpkin, G.T., Frese, M., 2009. Entrepreneurial orientation and business performance: An assessment of past research and suggestions for the future. Entrepreneurship: Theory \& Practice 33 (3), 761 787.

Reitzig, M., 2003. What determines patent value?: Insights from the semiconductor industry. Research Policy 32 (1), 13-26.

Richard, O.C., Barnett, T., Dwyer, S., Chadwick, K., 2004. Cultural diversity in management, firm performance, and the moderating role of entrepreneurial orientation dimensions. Academy of Management Journal 47 (2), 255-266.

Rivis, A., Sheeran, P., Armitage, C.J., 2009. Expanding the affective and normative components of the theory of planned behavior: A meta-analysis of anticipated affect and moral norms. Journal of Applied Social Psychology 39 (12), 2985-3019.

Sampat, B.N., Mowery, D.C., Ziedonis, A.A., 2003. Changes in university patent quality after the bayh-dole act: A re-examination. International Journal of Industrial Organization 21 (9), 1371-1390.

Sampat, B.N., 2006. Patenting and US academic research in the 20th century: The world before and after BayhDole. Research Policy 35 (6), 772-789.

Schein, E.H., 1983. The role of the founder in creating organizational culture. Organizational Dynamics 12 (1), $13-28$.

Sellenthin, M., 2009. Technology transfer offices and university patenting in Sweden and Germany. The Journal of Technology Transfer 34 (6), 603-620. 
Shane, S., 2001. Technology regimes and new firm formation. Management Science 47 (9), 1173-1190.

Shane, S., 2002. Selling university technology: Patterns from MIT. Management Science 48 (1), 122-137.

Shane, S., 2004a. Encouraging university entrepreneurship? The effect of the Bayh-Dole act on university patenting in the United States. Journal of Business Venturing 19 (1), 127-151.

Shane, S.A., 2004b. Academic entrepreneurship: University spinoffs and wealth creation. Elgar, Cheltenham et al.

Song, M., Podoynitsyna, K., van der Bij, H., Halman, J.I.M., 2008. Success factors in new ventures: A metaanalysis. Journal of Product Innovation Management 25 (1), 7-27.

Statistisches Bundesamt, 2010. Bildung und kultur: Monetäre hochschulstatistische kennzahlen. Statistisches Bundesamt, Wiesbaden.

Thomä, J., Bizer, K., 2013. To protect or not to protect? Modes of appropriability in the small enterprise sector. Research Policy 42 (1), 35-49.

Thursby, J., Fuller, A.W., Thursby, M., 2009. US faculty patenting: Inside and outside the university. Research Policy 38 (1), 14-25.

Thursby, J.G., Thursby, M.C., 2002. Who is selling the ivory tower? Sources of growth in university licensing. Management Science 48 (1), 90-104.

Van Looy, B., Callaert, J., Debackere, K., 2006. Publication and patent behavior of academic researchers: Conflicting, reinforcing or merely co-existing? Research Policy 35 (4), 596-608.

Van Looy, B., Landoni, P., Callaert, J., van Pottelsberghe, B., Sapsalis, E., Debackere, K., 2011. Entrepreneurial effectiveness of European universities: An empirical assessment of antecedents and trade-offs. Research Policy 40 (4), 553-564.

Vuong, Q.H., 1989. Likelihood ratio tests for model selection and non-nested hypotheses. Econometrica 57 (2), 307-334.

Wright, M., Lockett, A., Clarysse, B., Binks, M., 2006. University spin-out companies and venture capital. Research Policy 35 (4), 481-501.

Zibin, X., Parry, M.E., Song, M., 2011. The impact of technology transfer office characteristics on university invention disclosure. IEEE Transactions on Engineering Management 58 (2), 212-227.

Zucker, L.G., Darby, M.R., Brewer, M.B., 1998. Intellectual human capital and the birth of U.S. Biotechnology enterprises. American Economic Review 88 (1), 290-306.

Zucker, L.G., Darby, M.R., Armstrong, J.S., 2002. Commercializing knowledge: University science, knowledge capture, and firm performance in biotechnology. Management Science 48 (1), 138-153. 
Figure 1

Frequency of patent family applications relative to incorporation

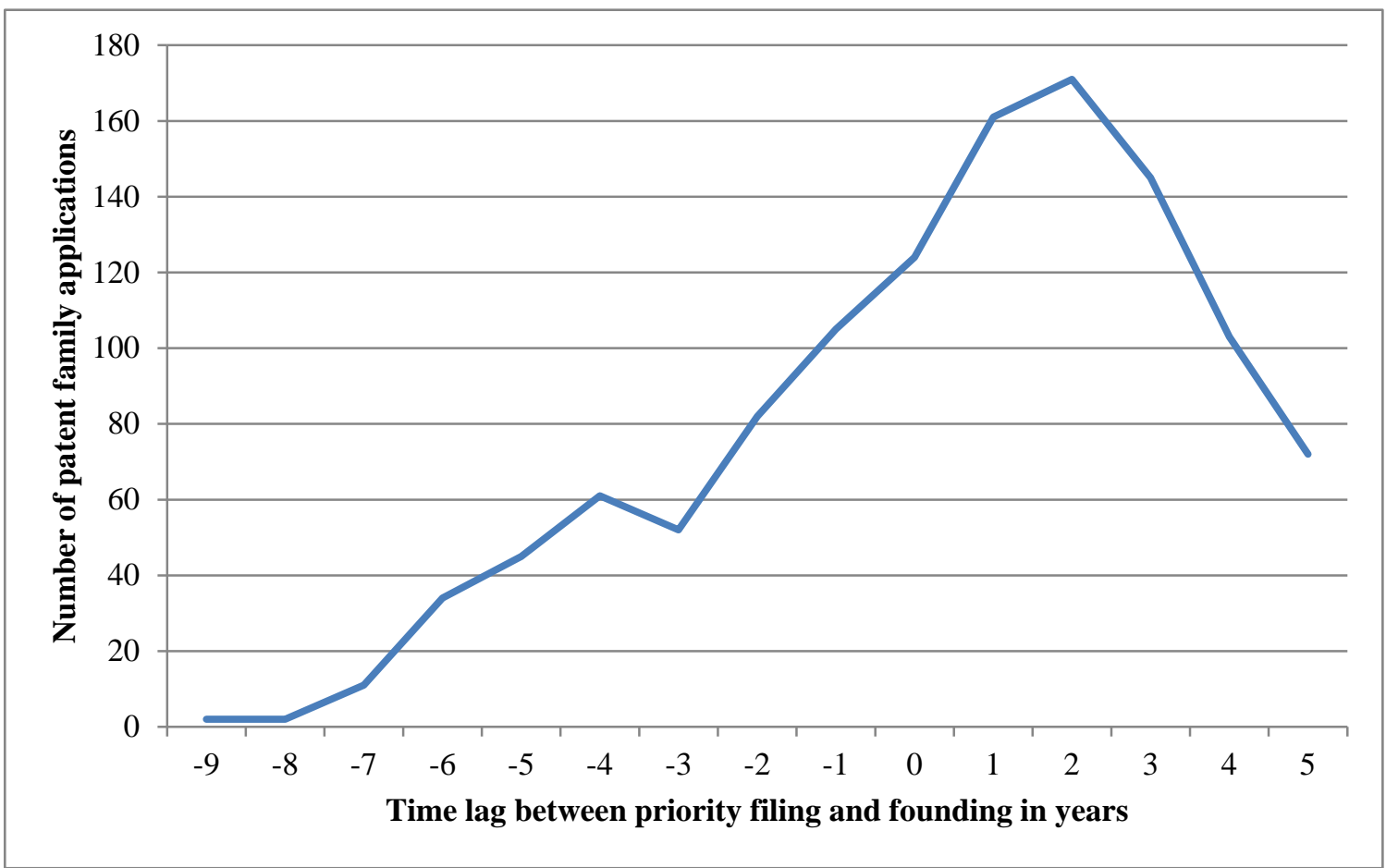




\section{Table 1}

Descriptive statistics and correlations for weak organizational regimes (public universities). ${ }^{\mathrm{a}}$

\begin{tabular}{|c|c|c|c|c|c|c|c|c|c|c|c|c|c|c|c|c|}
\hline Variable & Min & Max 1 & Mean & SD & 1 & 2 & 3 & 4 & 5 & 6 & 7 & 8 & 9 & 10 & 11 & 12 \\
\hline 1.Number of patent family applications & .00 & 55.00 & 3.32 & 7.59 & - & & & & & & & & & & & \\
\hline 2.Expert knowledge & 1.00 & 7.00 & 5.19 & 1.20 & .13 & - & & & & & & & & & & \\
\hline 3.Entrepreneurial orientation & 4.00 & 20.00 & 14.27 & 3.06 & .11 & $.24^{*}$ & - & & & & & & & & & \\
\hline 4.Organizational patenting norms & .00 & .16 & .00 & .02 & $.21^{\mathrm{t}}$ & -.05 & -.10 & - & & & & & & & & \\
\hline 5.Organizational patenting capabilities & .00 & 1.00 & .32 & .37 & .02 & -.06 & .11 & $.22^{\mathrm{t}}$ & - & & & & & & & \\
\hline 6.Organizational publication norms & .00 & 2.54 & 1.00 & .54 & .13 & .12 & -.07 & .09 & -.14 & - & & & & & & \\
\hline 7.Focus on applied research & 6.25 & 73.34 & 4.39 & 14.86 & -.05 & -.12 & $.23^{*}$ & $.33^{* *}$ & $.43^{* * *}$ & -.14 & - & & & & & \\
\hline 8.Patent effectiveness & 3.63 & 5.84 & 4.65 & 1.18 & $.25^{*}$ & $.21^{\mathrm{t}}$ & .07 & .06 & -.04 & .05 & .04 & - & & & & \\
\hline 9.Technological uncertainty & 1.00 & 7.00 & 3.76 & 1.35 & .08 & -.04 & .01 & -.04 & -.06 & -.04 & -.06 & $.27^{*}$ & - & & & \\
\hline 10.Venture capital ${ }^{\mathrm{b}}$ & .00 & 1.00 & .19 & .39 & .01 & .01 & .03 & -.09 & -.04 & .08 & .01 & .17 & $.22^{*}$ & - & & \\
\hline 11.R\&D intensity & .16 & 1.00 & .74 & .22 & .09 & -.07 & -.11 & -.16 & .04 & .03 & .17 & .14 & $.20^{\mathrm{t}}$ & -.05 & - & \\
\hline 12.Number of publications & .00 & 363.00 & 21.01 & 54.56 & $.30^{* *}$ & .08 & -.08 & $.70^{* * *}$ & .06 & .15 & .08 & .10 & -.03 & .11 & .13 & - \\
\hline 13.Number of previous patents & .00 & 11.00 & .59 & 2.04 & $.27^{*}$ & .06 & .07 & $.57^{* * *}$ & $.20^{\mathrm{t}}$ & .05 & $.24^{*}$ & .15 & .01 & -.08 & .03 & $.55^{* * *}$ \\
\hline
\end{tabular}




\section{Table 2}

Descriptive statistics and correlations for strong organizational regimes (public research organizations). ${ }^{\mathrm{a}}$

\begin{tabular}{|c|c|c|c|c|c|c|c|c|c|c|c|c|c|c|c|c|}
\hline Variable & Min & Max & Mean & SD & 1 & 2 & 3 & 4 & 5 & 6 & 7 & 8 & 9 & 10 & 11 & 12 \\
\hline 1.Number of patent family applications & .00 & 109.00 & 5.27 & 13.69 & - & & & & & & & & & & & \\
\hline 2.Expert knowledge & 1.00 & 7.00 & 5.18 & 1.37 & .06 & - & & & & & & & & & & \\
\hline 3.Entrepreneurial orientation & 7.17 & 21.00 & 13.79 & 3.20 & $.22^{\mathrm{t}}$ & .16 & - & & & & & & & & & \\
\hline 4.Organizational patenting norms & .00 & .68 & .17 & .13 & -.05 & .04 & .01 & - & & & & & & & & \\
\hline 5.Organizational patenting capabilities & .00 & .91 & .49 & .21 & .07 & .12 & -.02 & $.46^{* * *}$ & - & & & & & & & \\
\hline 6.Organizational publication norms & .00 & 48.97 & $7 \quad 1.31$ & 5.51 & -.02 & .01 & .05 & .06 & $-.22^{*}$ & - & & & & & & \\
\hline 7.Focus on applied research & 9.44 & 182.06 & 565.09 & 53.66 & -.12 & .05 & -.04 & $.54^{* * *}$ & $.37^{* * *}$ & -.09 & - & & & & & \\
\hline 8.Patent effectiveness & 3.63 & 5.84 & $4 \quad 4.65$ & 1.18 & $.23^{*}$ & -.15 & -.07 & .04 & .04 & .10 & -.13 & - & & & & \\
\hline 9.Technological uncertainty & 1.00 & 6.33 & 33.67 & 1.53 & .00 & .11 & .16 & .09 & .15 & -.02 & -.04 & -.19 & - & & & \\
\hline 10.Venture capital ${ }^{\mathrm{b}}$ & .00 & 1.00 & .18 & .38 & .16 & -.13 & $.29^{*}$ & -.14 & .01 & .15 & -.11 & $.27^{*}$ & .02 & - & & \\
\hline 11.R\&D intensity & .08 & 1.00 & .79 & .20 & -.05 & $.24^{*}$ & -.11 & -.11 & .07 & -.10 & .01 & .00 & .06 & -.06 & - & \\
\hline 12.Number of publications & .00 & 853.00 & 32.671 & 103.61 & .06 & .00 & .03 & -.06 & .03 & .04 & -.17 & $.24^{*}$ & -.09 & .20 & .00 & - \\
\hline 13.Number of previous patents & .00 & 7.00 & .67 & 1.30 & $.22^{*}$ & .15 & -.04 & .05 & $.24^{*}$ & -.08 & .02 & $.29^{*}$ & -.06 & -.11 & -.09 & $.22 \mathrm{t}$ \\
\hline
\end{tabular}

13.Number of previous patents

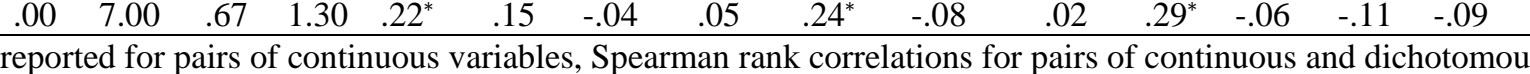

$\mathrm{a} n=79$. Pearson product moment correlations are reported for pairs of continuous variables,
variables. ${ }^{\mathrm{b}}$ Coding: $1=$ at least one venture capitalist holds stakes in firm equity, $0=$ else.

${ }^{\mathrm{t}} \mathrm{p}<.10$

${ }_{* *}^{*} \mathrm{p}<.05$

${ }^{* *} \mathrm{p}<.01$

${ }^{* * *} \mathrm{p}<.001$ (two-tailed test). 
Table 3

Results for regression analyses of patent propensity. ${ }^{\text {a }}$

\begin{tabular}{|c|c|c|c|c|c|c|c|c|c|c|c|c|c|c|c|c|}
\hline \multirow[b]{3}{*}{ Founding team characteristics } & \multicolumn{8}{|c|}{ Weak organizational regimes (Universities) } & \multicolumn{8}{|c|}{ Strong organizational regimes (Research organizations) } \\
\hline & \multicolumn{2}{|c|}{$\begin{array}{c}\text { Model } 1 \\
\text { 6-year w. }\end{array}$} & \multicolumn{2}{|c|}{$\begin{array}{c}\text { Model } 2 \\
\text { 8-year w. } \\
\end{array}$} & \multicolumn{2}{|c|}{$\begin{array}{c}\text { Model } 3 \\
\text { 10-year w. }\end{array}$} & \multicolumn{2}{|c|}{$\begin{array}{c}\text { Model } 4 \\
\text { Avg. }^{\text {effect }}{ }^{\mathrm{b}} \\
\end{array}$} & \multicolumn{2}{|c|}{$\begin{array}{c}\text { Model } 5 \\
\text { 6-year w. } \\
\end{array}$} & \multicolumn{2}{|c|}{$\begin{array}{c}\text { Model } 6 \\
\text { 8-year w. }\end{array}$} & \multicolumn{2}{|c|}{$\begin{array}{c}\text { Model } 7 \\
\text { 10-year w. }\end{array}$} & \multicolumn{2}{|c|}{$\begin{array}{c}\text { Model } 8 \\
\text { Avg. effect }^{\mathrm{b}} \\
\end{array}$} \\
\hline & $\mathrm{b}$ & S.E. & $\mathrm{b}$ & S.E. & $\mathrm{b}$ & S.E. & $\mathrm{b}$ & S.E. & $\mathrm{b}$ & S.E. & $\mathrm{b}$ & S.E. & $\mathrm{b}$ & S.E. & $\mathrm{b}$ & S.E. \\
\hline Expert knowledge & $.40^{*}$ & .20 & $.35^{*}$ & .17 & $.43^{*}$ & .17 & $.39^{*}$ & .18 & .11 & .16 & .09 & .15 & .21 & .15 & .14 & .15 \\
\hline Entrepreneurial orientation & $.20^{*}$ & .09 & $.20^{*}$ & .09 & $.22^{* *}$ & .08 & $.20^{*}$ & .09 & .06 & .07 & .05 & .08 & .06 & .08 & .06 & .08 \\
\hline \multicolumn{17}{|l|}{ Organizational characteristics } \\
\hline Organizational patenting norms & -6.60 & 13.51 & 16.15 & 15.96 & -41.06 & 27.13 & -1.50 & 18.87 & $4.07^{* *}$ & 1.34 & $3.41^{*}$ & 1.62 & 2.91 & 1.84 & $3.46^{*}$ & 1.60 \\
\hline Organizational patenting capabilities & .66 & .56 & .32 & .63 & .44 & .60 & .47 & .60 & .91 & 1.19 & 1.07 & 1.30 & $2.26^{\mathrm{t}}$ & 1.27 & 1.41 & 1.25 \\
\hline Organizational publication norms & .33 & .55 & .01 & .54 & -.02 & .47 & .11 & .52 & .00 & .01 & .01 & .01 & .00 & .01 & .00 & .01 \\
\hline \multicolumn{17}{|l|}{ Control variables } \\
\hline Organizational focus on applied research & $-.05^{* *}$ & .02 & $-.04^{*}$ & .02 & $-.04^{* *}$ & .01 & $-.04^{* *}$ & .02 & $-.01^{*}$ & .00 & $-.01^{\mathrm{t}}$ & .00 & -.01 & .00 & $-.01^{\mathrm{t}}$ & .00 \\
\hline Patent effectiveness & $.66^{* * *}$ & .17 & $.79^{* * *}$ & .19 & $.79^{* * *}$ & .19 & $.75^{* * *}$ & .18 & .03 & .19 & .02 & .19 & .17 & .17 & .08 & .18 \\
\hline Technological uncertainty & .21 & .19 & .22 & .19 & .19 & .19 & .21 & .19 & .03 & .13 & .08 & .12 & .07 & .12 & .06 & .12 \\
\hline Venture capital $^{\mathrm{b}}$ & -.08 & .52 & .26 & .55 & -.29 & .55 & -.04 & .54 & $2.12^{* *}$ & .71 & $2.15^{* *}$ & .73 & $1.74^{* *}$ & .66 & $2.00^{* *}$ & .70 \\
\hline R\&D intensity & $3.66^{* * *}$ & 1.05 & $3.71^{* * *}$ & * 1.00 & $4.06^{* * *}$ & .97 & $3.81^{* * *}$ & * 1.01 & .50 & 1.06 & .05 & .91 & -.66 & .86 & -.04 & .94 \\
\hline Number of publications & .01 & .01 & .01 & .01 & $.02^{\mathrm{t}}$ & .01 & .01 & .01 & .00 & .00 & .00 & .00 & .00 & .00 & .00 & .00 \\
\hline Number of previous patents & .16 & .13 & .15 & .16 & .35 & .35 & .22 & .21 & $.56^{* * *}$ & .14 & $.60^{* * *}$ & * .16 & $.57^{* *}$ & .21 & $.58^{* *}$ & .17 \\
\hline Log likelihood & -139.74 & & -152.12 & & -158.18 & & -150.01 & & -168.83 & & -181.09 & & -192.29 & & -180.74 & \\
\hline Wald chi-square & $185.94^{* * *}$ & & $265.47^{* * *}$ & & $162.67^{* * *}$ & & $204.69^{* * *}$ & & $45.95^{* * *}$ & & $55.68^{* * *}$ & & $76.23^{* * *}$ & & $59.29^{* * *}$ & \\
\hline
\end{tabular}

${ }^{\mathrm{a}} \mathrm{n}=79$ for universities and research organizations, respectively. Robust standard errors clustered at organizational level. ${ }^{\mathrm{b}}$ Average effect over all examined time periods. ${ }^{c}$ Coding: $1=$ at least one venture capitalist holds stakes in firm equity, $0=$ else.

${ }^{\mathrm{t}} \mathrm{p}<.10$

${ }^{*} \mathrm{p}<.05$

${ }_{* * *} \mathrm{p}<.01$

$\mathrm{p}<.001$ (two-tailed). 
Expert knowledge $(\alpha=.71, \mathrm{CR}=.77$, AVE $=.53)$

Members of the founding team were considerably involved in technological breakthroughs $\quad .75$ in my company's technological field.

Knowledge about the operational principles of my company’s core technology was widely $\quad$.68 disseminated in the scientific community. (r)

Competitors were able to very quickly learn about the core technology from public sources $\quad .74$ (books, journals, internet, etc.) to the point of being able to implement it. (r)

Entrepreneurial Orientation: Innovativeness $(\alpha=.75, \mathrm{CR}=.76, \mathrm{AVE}=.62)$

Our company has introduced many new products or services over the past three years.

Changes in products or service lines have usually been quite dramatic.

Entrepreneurial Orientation: Proactiveness $(\alpha=.64, \mathrm{CR}=.70, \mathrm{AVE}=.44)$

Our company undertakes great efforts to find new applications for our core technologies and $\quad .65$ to open new markets for our existing products/services.

Our company introduces new technologies and methods for the production of our $\quad .62$ products/services long before our competitors do so.

My company typically waits until other companies introduce new products/services to the .72 market before introducing new products/services. (r)

Entrepreneurial Orientation: Risk-taking $(\alpha=.70, \mathrm{CR}=.71, \mathrm{AVE}=.55)$

Over the past three years, our company has engaged in very many high-risk projects with $\quad .73$ chances of very high returns.

Our company has emphasized taking bold, wide-ranging and capital-intensive actions in $\quad .75$ positions itself and its products/services over the past three years.

Technological uncertainty $(\alpha=.77, \mathrm{CR}=.80, \mathrm{AVE}=.60)$

It was easy to understand, which other technologies our company required besides our core technology to create marketable products (r).

The time to develop our core technology to marketability could be clearly estimated. (r)

$\mathrm{r}=$ reverse coded,$\alpha=$ Cronbach's Alpha; $\mathrm{CR}=$ Composite Reliability; AVE $=$ Average Variance Explained; Model fit: $\chi^{2} / \mathrm{df}=1.59 ; \mathrm{GFI}=.92 ; \mathrm{AGFI}=.89$, RMSEA $=.05$. 